\title{
The 'crisis' in defined benefit corporate pension liabilities \\ Part I: Scope of the problem
}

Received (in revised form): 23rd October, 2006

\begin{abstract}
Gordon L. Clark
is the Halford Mackinder Professor of Geography at the University of Oxford and Professorial Fellow of St Peter's College, Oxford. He is also a senior research fellow at Harvard University's Labor and Worklife Program. The author of Pensions and Corporate Restructuring in American Industry (Johns Hopkins University Press, 1993), Pension Fund Capitalism (Oxford University Press, 2000), and European Pensions \& Global Finance (OUP, 2003), he is the co-editor of The Oxford Handbook of Pensions and Retirement Income (OUP, 2006).
\end{abstract}

\section{Ashby H. B. Monk*}

is a PhD candidate at Christ Church, University of Oxford. His doctoral research focuses on the impact of competitive strategy and globalisation on the design and implementation of corporate benefit systems. He holds graduate and undergraduate economics degrees from the Sorbonne (Paris I) and Princeton University, respectively.

\begin{abstract}
Once an integral component of company-sponsored compensation schemes in many Western economies, private defined benefit (DB) pensions are in decline. For many, DB schemes (and their related healthcare liabilities, depending on the jurisdiction) have hobbled the financial well being of plan sponsors and even whole sectors of industry. If a constraint on shareholder value in the shortterm, these schemes threaten long-term corporate survival in the emerging global economy. While there remains considerable debate over the ability of financial markets to adequately price DB liabilities, there is a growing industry devoted to estimating their long-term risks with respect to longevity, inflation and cost. In this two-part paper, we begin by surveying the nature and significance of the problem, focusing upon UK and US private employer-sponsored plans. It is suggested that the 'crisis' was apparent, for those willing to look, a decade ago. Its significance was papered-over by the 1990s stock market bubble and high interest rates but has returned through what many analysts identify as a 'perfect storm'. Having documented the nature and scope of the 'perfect storm' in part I, we then evaluate the proffered solutions to the crisis in part II, focusing on financial engineering, government intervention and private sector negotiation. In the final sections of the paper, we set out the principles that should guide the design of new kinds of employer-sponsored plans noting that if, as suggested by many experts, Western economies are entering an era of increasing labour shortage, private pensions will continue to have an important role in managing human capital.
\end{abstract}

Pensions (2006) 12, 43-54. doi:10.1057/palgrave.pm.5950041

Keywords: pension crisis, pension liability, pension reform

\section{Introduction}

Defined benefit (DB) pensions are present-day corporate burdens, inherited from a past generation of employees and managers that, in

*Correspondence: Ashby H. B. Monk, Oxford University Centre for the Environment, Oxford, OX1 3QY, UK.

Email: ashby.monk@chch.ox.ac.uk severe cases, jeopardise the very solvency of their sponsoring firms. The DB pension model in the private sector is at great risk, as highly publicised instances of underfunding and the prospect of plan failures threaten an entire institution that was once thought inviolate. ${ }^{1}$

Past: DB pension systems were built incrementally ('brick-by-brick') over the course of more than 50 years. Each additional 
'improvement' to plan benefits was relatively small, with little in the way of individual accountability for the accumulating costs and growing risks despite the fact that these costs and risks were (and are) substantial., ${ }^{2,3}$ Moreover, thanks to countervailing financial market trends, DB pensions became huge financial institutions within the private sector. The strength of the equities market and relatively high interest rates (at different moments) made each benefit increase or contribution holiday appear sustainable at a given point in time. In addition, UK and US governments facilitated DB pension growth via tax breaks for most categories of employment. Trends such as these deflected any acknowledgement of the true costs and risks of DB pensions, allowing plan sponsors and their advisors to deny the existence of a problem. ${ }^{4-6}$

In fact, close-at-hand but largely ignored, were three difficult-to-hedge risks that would prove devastatingly costly to DB pensions. First, mortality experience directly influences a company's cash payouts since improving life expectancy increases the number of retirees entitled to benefits. Failure to anticipate future improvements in longevity have proven costly. Second, inflation risk can be serious for those firms that index pension benefits, since it complicates the task of estimating liabilities over the long term. ${ }^{7}$ Third, cost risks, which refer to the vulnerability of the plan sponsor to wage inflation and regulatory changes, have proven significant over the past few decades. These 'unhedgeables' are key variables within DB benefit plans and render the sponsor particularly vulnerable to their volatility. Ultimately, when the stock market bubble burst in 2001 and real interest rates dropped, the 'brick-by-brick' additions of these costs and risks were finally exposed to be a huge burden on plan sponsors: firms found themselves up against a brick wall.,

Present: Plan sponsors, having inherited longevity, inflation and cost risks from past generations, are faced with difficult choices given that the post-bubble environment of modest growth in assets and low interest rates has amplified the magnitude of the problem. Indeed, rapid and unanticipated increases in pension obligations have put at risk some of the largest corporations on both sides of the Atlantic. ${ }^{10}$ Reminiscent of the US Savings and Loan catastrophe of the 1980s, the prospect of a multiindustry government bailout has emerged over the last five years as firms look to shed their pension liabilities in any way possible.

Remediation of past problems is, however, proving difficult due to clashes between private and public solutions to the pension crisis. Now more than ever, there is a need to reinvigorate private involvement to avoid institutional failure and government bailout. Ideally, private solutions should redistribute risks and costs of contributions thereby rendering DB pensions 'manageable'.

Current government regulation in the form of benefit insurance (PBGC, PPF), bankruptcy (Chapter 11) and funding rules (ERISA, Pension Protection Act, Pensions Act 2004) are, however, having market distorting effects due, in part, to moral hazard, stymieing the private sector process of resolution by making public institutions a first-order choice. ${ }^{11}$

Future: The increased possibility of institutional failure warrants a plan of action. If negotiated solutions were viable, if government regulation could be changed to alter the incentives pushing firms towards bankruptcy and if the 'unhedgeables' could be countered with innovative financial or insurance products, then a path towards more sustainable single employersponsored DB pensions might be possible. Indeed, DB-type pensions may be once again favoured by employers looking to a future likely characterised by increasing shortages of skilled labour. The fact that these conditions are difficult to specify let alone meet, however, demonstrates why the pension crisis is in fact a 'crisis'. Firms like General Motors are emblematic of the gathering disaster.

Plan of action: This two-part paper has eight sections. In part I, we begin by arguing that the pension crisis is the product of overly risky investment strategies for pension assets with little or no regard for pension liabilities (section one). This is combined with a dysfunctional pension construct that handicaps businesses in an era of heightened market competition (section two). It is 
shown that the impact of the DB pension crisis, notwithstanding bailouts restricted to a narrow set of firms and industries, could be wide-ranging (section three). In part II, we suggest that the current toolbox of solutions, such as negotiated agreements between the implicated parties (section four), government regulation (section five), and financial products structured to better match with liabilities (section six) are inadequate. Subsequently, we show that the dearth of viable long-term solutions stems, in part, from an inability to reduce the high cost of $\mathrm{DB}$ pension obligations, since contributions must be high enough to pay for what may be decades of inactivity (section seven). Finally, we argue that distributing the high cost of occupational pensions in a manner that does not impact in unintended ways the core operations of the plan sponsor is necessary (section eight).

We conclude part II with a road map for plan sponsors intent on evolving towards less constricting pension provisions. We believe DB plan sponsors have four available options. Plan A suggests that removing the DB pension and replacing it by an 'intelligent' defined contribution pension, although extremely difficult and costly, may be the best option for the long term. ${ }^{12}$ Plan $B$ offers the 'next best' solution, suggesting that an innovative remade DB pension model, such as a hybrid pension, could be effective. Plan C offers an option for firms that can neither implement $A$ nor B. It proposes using a multi-employer DB pension as a way of minimising risks to sponsors. Finally, plan D is a non-employer contributive pension option. ${ }^{13}$ In all cases, our paper concludes that the path forward should be a private-sector solution (perhaps facilitated by government interventions) that achieves a new pension structure in which workers, employers and shareholders share the pension cost (though perhaps not the pension risk) cooperatively and fairly for the benefit of all parties.

\section{Managing the burden}

\section{Rose-coloured glasses}

By 2002, underfunding among DB pension plan sponsors in the UK and US was widespread, causing alarm and spurring government inquiries on both sides of the Atlantic. ${ }^{14-16}$ Many argued that the pension crisis stemmed from investment and funding policies that failed to account for the latent risks inherent to $\mathrm{DB}$ pension obligations, and the complicated and opaque actuarial assumptions as well as accounting methods and rules had obfuscated pension costs and obligations. Particularly important in the US, plan sponsors were afforded by government and professional bodies high levels of discretion in calculating and funding their pension obligations, allowing them to ignore their most pressing problem exploding pension liabilities — while maintaining the façade of stability. ${ }^{17}$ Below is a discussion of these factors.

Asset management: With pension assets averaging double-digit returns in the 1990 s, pension plan trustees focused on pension asset management to the detriment of their pension liabilities. Meanwhile, they took advantage of high asset values and returns by taking contribution holidays, enabling benefit increases, introducing cost-of-living adjustments and increasing net income by reporting pension asset income as corporate income, all without triggering increased contributions. In fact, from 1995 to 2002 , roughly $2 / 3$ of the largest US plan sponsors made no cash contributions to their pensions due to accounting credits. ${ }^{18}$ Managing DB investment and benefit policies without regard to liabilities was comprehensible given the context but nonetheless precarious.

Indeed, experts today contend both that the equity risk premium has shrunk with little confidence of the gap re-opening in the future and that pension fund trustee competence with respect to capital investment strategies remains suboptimal. ${ }^{19-22}$ Undeniably, the rose-coloured glasses have come off and asset-liability management strategies are moving in reverse gear. The often cited trend among today's DB plan sponsors is 'risk immunisation', which takes liability management and matching to the extreme. Apparently, those that rode asset values and interest rates in the 1990s are now seeking long-dated government bonds in markets saturated by demand. 
Actuarial shortcomings: Plan sponsors' shortsighted behaviour during the bubble years was made possible, in part, by obscure and opaque funding rules. There were several reasons why even the 'best practice' guidelines for providing actuarial advice on funding targets were ineffective. ${ }^{23}$ Actuaries often incorporated expected returns on the backing pension assets when determining funding targets - or, more precisely, when determining the assets necessary to fully fund obligations. This meant that a riskier investment with a higher expected return could in fact lower the size of the funding contributions. Amplifying this concern, Cowling et al. ${ }^{24}$ in a paper to the UK Institute of Actuaries, expressed unease over 'an element of self delusion within the actuarial profession; regardless of the reference to expected returns, using a higher discount rate is simply a way of reducing the pace of funding, that is advising lower contributions now (at the expense of potentially higher contributions later and lower member security)'. This practice is the opposite of what would occur in the insurance industry, where riskier investments require more assets in order to secure the liability. ${ }^{24}$ The problem is the actuarial connection between assets and liabilities. What a fund does with its assets affects future funding levels, but this must remain separate from the current funding targets. ${ }^{25}$

In addition, actuaries have had difficulty anticipating the impact of increasing longevity on DB pensions notwithstanding their reliance on official life tables. ${ }^{26,27}$ According to US official life tables, in 1958 a 20-year-old American (men and women combined) could expect to live an average of 52.2 more years. In 2002, a 20-year old could expect to live another 58.2 years on average. Thus, plan sponsors, having agreed to a DB pension in 1958, might end up paying for six more years of employee benefits than planned. Academic research has shown that DB costs have increased by 1 per cent per year compounded annually due to increasing longevity. ${ }^{28,29}$ These longevity trends are apparent in all OECD countries. ${ }^{30}$

Moreover, improvements in longevity are set to continue into the future. The UK Government Actuary's Department predicted that one million people could live to the age of 100 by 2074 , as compared with only 10,000 today (though this figure could end up being more like 350,000 due to obesity and other health hazards). Overall, underestimating longevity has proven expensive for plan sponsors and is all the more damaging due to the unhedegeable nature of the risk. ${ }^{31,32}$

Accounting shortcomings: Nontransparent financial reporting was an equally important contributor to today's pension crisis. Although UK and international accounting practices have been reformed (witness FRS 17 and IAS 19), pension obligations and matching assets have been poorly reflected in US corporate balance sheets (though this is soon to change). Financial Accounting Standards Board (FASB) Statement 87 has allowed this information to be reported in the footnotes, resulting in balance sheets that are difficult to understand. As a CFO of a multibillion dollar plan sponsor told us, 'accounting for pensions is a dog's breakfast of assumptions and disclosures'.

Although Feldstein and Mørck ${ }^{33}$ believed financial markets could see through the 'pension veil', reservations remain over the ability and willingness of analysts and investors to properly assess pension deficits and surpluses in forming their valuations. Coronado and Sharpe ${ }^{34}$ showed that the market pays more attention to 'the flow of pension-induced accruals reported in the body of the income statement than to the marked-tomarket value of pension assets and liabilities reported in the footnotes'. Picconi ${ }^{35}$ showed that analysts and investors fail to adequately incorporate pension information in their corporate valuations, and Zion and Carcache ${ }^{17}$ argued that a change in current accounting practice towards more transparency would negatively impact company valuations for firms with underfunded pensions. Finally, Franzoni and Marin $^{36}$ found evidence of significant overvaluation for DB plan sponsors with large pension deficits. They contend that overvaluation stems from investors not fully incorporating pension plan underfunding into their calculations on future earnings and cash flows until the impact of the underfunding actually appears on the income statement. They also show that the 


\section{United States:}

- The shortfall of assets to liabilities for those firms in the S\&P 500 with DB pensions rose from roughly $11 \%$ in 2004 to $14 \%$ in 2005 , according to Bear Stearns.

- According to Credit Suisse, at the end of 2005 pension plan funding for the S\&P 500 was $\$ 145$ billion in deficit. This is a slight improvement on 2004 thanks to robust asset returns (roughly $11 \%$ ) and $\$ 58$ billion in plan sponsor contributions.

- According to Credit Suisse, at the end of 2005, 78 of the S\&P 500 firms were less than $70 \%$ funded.

- At the end of its fiscal year (9/30/05), the PBGC's liabilities were $\$ 79.2$ billion with matching assets of $\$ 56.5$ billion -- a deficit of $\$ 22.8$ billion. However this deficit would have been worse ( $\$ 25.7$ billion) had DB plan terminations announced after the fiscal year ended been included.

\section{United Kingdom:}

- In October 2006, the pension deficit amongst the FTSE 100 firms that sponsor a DB pension was roughly $£ 50$ billion, according to Watson Wyatt.

- In addition, amongst the same firms, funding levels averaged only $87 \%$ in October.

- The volatility of funding levels reflects the vulnerability of these firms to FRS 17 accounting calculations and the rationale behind the drive towards assets that better match their liabilities.

Figure 1: The current state of underfunding

market is consistently 'surprised' by the low earnings of underfunded plan sponsors. ${ }^{37,38}$

As a result, the FASB has announced it will reconsider all aspects of OPEB and pension accounting. The FASB is likely moving closer to international accounting standards and the markto-market approach, which does not allow for the many smoothing mechanisms currently available under US accounting regulations. ${ }^{39}$

\section{True burden exposed}

Some of the dangers of DB pension obligations were known decades before the pension crisis. High levels of inflation in the 1970s had discounted the real value of many retirees' benefits, and had prompted retiree demands for indexation. No doubt, this policy had merit, given beneficiary welfare, but it required care with respect to implementation. ${ }^{40}$ According to Feldstein, ${ }^{5}$ switching to a fully indexed pension for a male aged 65 years (assuming 6 per cent per annum) from a nominal pension benefit would increase the pension cost by 50 per cent. In order to sustain such costs, firms would have needed to institute a much lower starting pension benefit or a lower wage, or both, advice that was largely ignored. Instead, countervailing trends, in particular the strength of the asset market in the 1990s, distorted perceptions of these inherent risks and prompted postponement of a solution.

Perfect storm I: The current pension crisis can be viewed as a 'perfect storm' of low asset returns and interest rates. These financial factors resulted in a dramatic reversal in funding levels. So unexpected was the confluence of these two phenomena in 2001 and 2002 that few sponsors had run 'stress test' scenarios of such an outcome. Consequently, pension fund trustees, their advisors, and even asset managers did not anticipate such an event because it was outside their risk parameters. ${ }^{41}$ This had devastating effects on pension plans: as lower discount rates increased the value of expected liabilities, the assets intended to cover these liabilities fell dramatically in value. This perfect storm of declining interest rates and asset returns took Fortune 1000 plan sponsors from an average funding level of 122 per cent in 1999 to 76 per cent in $2002 .^{42}$ 
Perfect storm II: The actuarial implications of the first perfect storm set off a regulatory perfect storm that had dire consequences for plan sponsors. In a short period, UK pension funding regulations went from lax to strict, thereby exacerbating firms' funding schedules. ${ }^{43}$ As noted earlier, pension liabilities in the 1990s were offbalance sheet, funding schedules were relatively flexible and, anyhow, plans were healthy (according to the assessment methodologies used at the time). Today, the situation is drastically different, as regulators try to secure benefits and increase transparency. Now that liabilities are on (or moving onto) the balance sheet, there are also much stricter funding rules (eg US Pension Protection Act 2006 and the UK Pensions Act 2004). Also, the much-derided discretion afforded to plan sponsors, intended to keep costs at reasonable levels, is gone. Thus, in the current environment, with funding levels low and costs increasing, DB pension obligations represent enormous burdens on their sponsoring firms. Pension underfunding is a problem as yet to be resolved (See Figure 1 for details of funding levels in the UK and US).

Too risky: The rapid increase in pension costs over the past few years has demonstrated that plan sponsors have taken on unhedgeable risks that can no longer be concealed. Unveiling these risks led to an unexpected possibility: the traditional scapegoats for the pension crisis (accounting opacity, asset returns, interest rates, etc), rather than causing the crisis we know today, may have actually allowed traditional DB pensions to exist longer than they might have otherwise. Perhaps the DB plans inherited from the post WWII era were defunct long before the pension crisis, and the asset bubble of the 1990 s simply delayed their downfall? If this were true, it would suggest that a deeper set of issues are at the root of DB pension underfunding and closures in the UK and US.

\section{Market failure}

\section{Dispelling myths}

The dramatic bursting of the stock market bubble in 2001 and the decline in long-term interest rates exposed the dangers for $\mathrm{DB}$ plan sponsors. Indeed, traditional $\mathrm{DB}$ pensions have been described as unmanageable burdens for 21st century firms. ${ }^{44}$ Nevertheless, some academics, unions, employees, fund managers and even government representatives argue that DB pensions are sustainable, that pension liabilities are nothing more than debt, and that insurance markets offer DB pensions a sustainable solution or alternative. These myths must be dispelled before we undertake an in-depth examination of DB pensions' impact on sponsoring firms.

Not 'just debt': Various regulatory interventions since the 1970s in the UK and US had the effect of taking pension promises and making them pension guarantees akin to traditional debt. Pension liabilities, however, are not reliably quantifiable, not legally tradeable, not cheaply retireable and not easily transferable - in other words, not like traditional debt at all. How do you define property rights with respect to private DB pension benefits? ${ }^{45,46}$ The cash outflows promised in a DB pension do resemble bond coupons. The tail of the pension liability, however, has a much longer duration and the structure of the pension agreement creates special cases where bond-like valuations are no longer appropriate. ${ }^{47}$ The key differences between pension liabilities and traditional debt are the various 'unhedgeables' common to DB pension deals. These elusive risks translate into pension liabilities that affect sponsors' balance sheets in unpredictable ways, differentiating pension debt from generic corporate debt.

Not insurance: Owing to the unknowns associated with a DB pension, plan sponsors have recently sought to transfer the liability risk of their DB plans to insurers by purchasing bulk annuity plans. Many DB plan sponsors, however, had originally decided to manage their pensions in-house to avoid the higher costs associated with securing benefits with a life insurer. Insurance is not a preferred or even desirable alternative to a DB pension; insurance companies need to make a profit, have higher capital adequacy requirements and have lower legal tolerance for unhedgeable risks that leads to conservatism in pricing. 


\section{DB handcuffs}

Today, the ultimate responsibility of pension obligations remains with the plan sponsor, despite the fact that pension plans were established as separate entities with the specific task of covering benefits. Consequently, a mismatch of assets and liabilities in a DB scheme can have a serious impact on the valuation of the firm as a whole. Underfunding can, and does, result in the diversion of valuable capital to fill a gap in the sponsors' pension funds. ${ }^{25}$

Temporal dilemma: Given that pension contributions divert revenue away from investment, management is strongly motivated to keep pension contributions as low as possible. ${ }^{48,49}$ This creates a temporal conflict in which management must decide between (1) higher contributions today with lower levels of investment and lower market competitiveness in the future, or (2) higher levels of investment today with the likelihood of much higher pension contributions sometime in the future. ${ }^{50}$ As such, resolving this dilemma depends a great deal on the discount function of shareholders (ie how much they value today compared with tomorrow).

When industry peers have significantly lower pension contributions, the choice is clear-cut if nonetheless problematic. For example, in the US automotive sector, pension and medical expenses make up $\$ 1,360$ for each GM vehicle, but only $\$ 107$ for each Honda vehicle made in the US. ${ }^{51}$ Moreover, as restructuring at GM accelerates, more and more people are added to the roll of retirees, adding even more costs to the company pension plans. How can GM be expected to increase current contributions to its pension plans and maintain its long-term competitiveness against Honda? In this context, it seems reasonable to suggest that the current pension crisis is much more than just investment policy flaws or accounting and actuarial mistakes. Rather it is equally the product of successive managers' and workers' willingness to push DB funding obligations onto subsequent generations of managers and employees.

Corporate executives, such as GM CEO Rick Wagoner, have lobbied for government to address the issues. In his words, pension and healthcare liabilities 'put US manufacturers at a severe disadvantage to overseas competition...the cumulative effect of many well-intentioned policies that now harm American manufacturing and our nation's ability to compete effectively in the global market place'. ${ }^{52}$ Wagoner, like previous corporate manufacturing executives, is determined that lawmakers acknowledge the crippling effect of legacy costs. ${ }^{53}$ In an industry that has seen profit margins drop from roughly 8 to 3 per cent, automakers' pension costs directly impact the competitiveness of the sponsoring firms by siphoning money away from much needed research and development. ${ }^{54}$ In fact, after GM decided to freeze its 'white collar' DB pensions in March 2006 ('blue collar' pensions were safe due to union contracts), Wagoner said 'in many cases, our non-US based competitors do not have comparable legacy costs, because retirement benefits for employees and retirees in their home countries are more heavily government funded... So our legacy costs in pensions and health care are an area of significant competitive disadvantage for us. ${ }^{55}$ In 2003, GM contributed an astonishing $\$ 18.5$ billion to its US pension plans. ${ }^{56}$

Impaired capacity: GM's precarious situation is but one example of the crippling effect of legacy costs. Indeed, many of the problems faced by the modern firm stem from an escalation in prior commitments that impinge on its ability to respond to technological innovations. ${ }^{57}$ In effect, these prior commitments block firms from mobilizing their resources to compete successfully in the modern economy, leaving them stymied when struggling for survival. Capitalist economies by nature build and dismantle institutions according to incentives (positive and negative); that which was built should be destroyed once it is no longer useful or is counterproductive. All economies have inherited institutions that are in constant competition with newly created ones, reinforcing their existence in some cases and jeopardizing it in others. ${ }^{23}$ Competition can be regulated, but regulation may suppress or distort the innovation and renewal necessary for firms to react to an increasingly competitive world. 
'Knot of contracts': The DB pension was an important instrument for managing labour resources through to the $1980 \mathrm{~s}^{58}$ It created solidarity and loyalty among employees within growing firms while allowing for a livable retirement, thereby underpinning 30 years of economic growth. But the firm is an evolving entity. As such, it cannot be held to account for the way that pension deals were negotiated half a century ago. In essence, current pension deals are based on an obsolete conception of the firm. ${ }^{59,60}$ Even if traditional DB pension management could be streamlined, the changing nature of the Anglo-American firm is such that DB coverage rates of the 1970 s are unlikely to return. ${ }^{61}$ The large firm is increasingly a global entity, with new models of labour management, motivation and compensation. Whatever the private and social benefits of providing supplemental pensions, an analysis of occupational pension provision and crisis must take place from within the firm, since the original rationale for offering DB pensions was based on labour management not social justice. The inherited DB institution has resulted in a 'knot of contracts' that constrains firm renewal and renovation necessary for success in the global economy, not easily unravelled or renegotiated. ${ }^{62}$ The real challenge for the $21 \mathrm{st}$ century is to create pension structures that do not look back or freeze corporate evolution.

\section{Scope of the problem}

\section{Components of crisis}

Plan closures are increasing and widespread. Over the past three decades, the PBGC has taken over more than 3,600 plans. ${ }^{63}$ In the UK, roughly three quarters of the FTSE 100 firms have closed their DB pension to new entrants and some have unilaterally changed the pension promise for those people in the plan. While the pension crisis threatens to engulf governments in a massive bailout, it is actually restricted to a narrow set of firms in a narrow set of industries. From 1980 to 1998, while the percentage of US private workers with an occupational pension remained between 50 and 60 per cent, those with a DB private pension fell from 80 to 45 per cent. ${ }^{64}$ In 2003 ,
72 per cent of unionised employees participated in a DB pension, as compared with only 15 per cent of non-unionised workers. But private-sector union coverage in 2005 was only 7.8 per cent, and concentrated in select industries: 24 per cent of transportation and utilities workers, 21.4 per cent of telecommunications workers, 13 per cent of manufacturing workers, but only 2.3 per cent of financial services workers, 2.7 per cent of professional and business services workers and 3.1 per cent for leisure and hospitality workers. ${ }^{65}$

Big enough to fail: Paralleling union concentration, the pension crisis has been limited to a handful of industries: the steel industry in the 1980s, the airline industry today and the automotive industry tomorrow. Certain firms are particularly vulnerable to DB's 'knot of contracts'. These are large manufacturing firms in global industries with highly unionized local workforces, offering generous, open (or in some cases closed) DB pensions.

There are several reasons why these types of firms are particularly vulnerable. First, market competition is forcing these firms and industries to reevaluate and close large segments of their inherited production capabilities. Second, higher real incomes worldwide have encouraged more taste-based consumption decisions, rather than need-based decisions. Finally, the never-ending quest for product differentiation and market segmentation has forced firms to innovate and develop many new products to fill ever-expanding demand. ${ }^{66}$ Thus, niche products threaten the scale of large manufacturing firms' product-lines, attacking both the nature and level of employment by production unit (and ultimately the demand for DB plans) precipitating institutional or organisational transformation.

To compete in the global economy of tomorrow, innovation must be quick and efficient, in ways that allow for cost-effective production and competitive pricing. ${ }^{67}$ Flexible production lines, both onshore and off, are increasingly in demand. Firms burdened with DB pension obligations may be too slow and cumbersome to be successful in this challenging environment. Likewise, the burgeoning medical expenses of US firms - union and non union - engender 
similar problems to DB pension liabilities. DB pensions have special status because the pension crisis is so concentrated in certain private sector industries. While market competition tightens in the face of globalisation, the benefit structures of whole countries may be put in play.

\section{Evaluating welfare}

Within the current pension crisis are issues of equity and well being. Denying pension promises after they have been accrued and maintaining pension promises at the expense of later generations diminish the welfare of current and future retirees. Pension plans have had very important social roles, inside and outside of the plan sponsor, and default has serious implications for workers and retirees and their communities. Moreover, the most popular alternative, DC pensions, are far from being reliable mechanisms for providing adequate retirement security. This is a problem for future generations of taxpayers and could become a second dimension of a longrunning pension crisis for much of the developed world. ${ }^{9}$

Longevity and participation: It was only after WWII that extended retirement years became commonplace and employer-provided pension plans became an integral part of national retirement systems. ${ }^{68}$ Over the same time-frame, the average health of people has improved, the intensity of physical labour in the manufacturing sector has diminished, and computerisation has enabled older people to work longer in today's economy. ${ }^{69}$ Even so, labour force participation rates of older generations have fallen. In 1940, two-thirds of US men aged 65 years participated in the workforce, compared with only 38 per cent in 2001. ${ }^{69}$ Likewise, over the course of the 20th century, in the UK the average retirement age fell despite huge gains in longevity. ${ }^{70,71}$ Evidently, any attempt to reform DB occupational pensions has to come to grips with changes in labour market participation.

Job production: Despite the collective interest in retirement benefits, we must acknowledge the collective interest in the economic competitiveness of firms. If one accepts that inherited DB pension burdens are like a 'sandbag' on corporate dynamism, then the presence of a DB pension could ultimately create problems for market competitiveness and translate into fewer jobs created. The social benefits of vital jobproducing industries are perhaps greater than the generous pension benefits for retirees (especially if we acknowledge how isolated those people are in the private sector with access to open DB schemes). To think otherwise is to privilege a select group of retirees over current workers, giving the older generation a claim to resources that could secure their children's long-term interests.

\section{Conclusion}

Once an integral component of companysponsored compensation schemes in many Western economies, DB pensions have hobbled the financial well being of plan sponsors and even whole sectors of industry. In some extreme cases, these schemes threaten corporate survival in the global economy. While asset management, actuarial and accounting shortcomings set the stage for the 'perfect storm', the actual impetus for the present 'pension crisis' is more complicated. Given the tumultuous nature of capitalism, the inherited DB institution constrains firm renewal and renovation necessary for success in the global economy. DB plans sponsors are tied to the past, forced to face the future with inefficient organisational structures and competitive strategies.

In part II, we turn to the proffered solutions to the crisis, focusing on financial developments, government interventions and private sector negotiations. However, given that the current set of tools has not resolved the crisis, we must acknowledge that there is no 'silver bullet'. As such, we set out principles that could guide the design of new kinds of employer-sponsored plans noting that if, as suggested by many experts, western economies are entering an era of increasing labour shortage, private pensions will continue to have an important role in managing human capital.

This discussion will continue in 'Part II: The 'Crisis' in Defined Benefit Corporate Pension 


\section{Liabilities: Current Solutions and Future Prospects' in the next issue of Pensions.}

\section{Acknowledgments}

Support for this paper was provided, in part, by the Lupina Foundation (Toronto), the Transport Studies fund at Oxford and The British Academy, being drawn from a larger research project on pension fund and healthcare liabilities in the private sector. The authors would also like to thank Christ Church for partially funding necessary travel. Helpful comments at various stages on the project were made by Keith Ambachtsheer, Teresa Ghilarducci, Tessa Hebb, Divyesh Hindocha, Ian Mills, Courtney Monk, Michael Orszag, Dallas Salisbury and Roger Urwin. The results and interpretations reported are the sole responsibility of the authors; none of the above should be held to account for any errors, omissions, or opinions expressed herein.

\section{References and Notes}

1 While each industry has its own story to why DB is no longer working (legacy costs, moral hazard, etc), the broad consensus zat a recent high-level conference on pension liabilities organised by the authors (that brought together roughly 50 acknowledged (pension experts') was that the current private sector single employer DB pension system may not be sustainable over the long term (See www.ouce.ox.ac.uk/news/ phclcs/for details on the pension liabilities conference held May 26, 2006).

2 We do not believe people at the time were able to look forward to calculate the cumulative consequences of their actions - this is a statement of interpretation (ie from interviews) and a statement of individuals' cognitive abilities (see Kahneman and Tversky, 1979).

3 Kahneman, D. and Tversky, A. (1979) 'Prospect theory: An analysis of decisions under risk', Econometrica, Vol. 47, pp. 263-291.

4 Still, 25 years ago the problems were already apparent to some (Feldstein, 1981, and Feldstein and Seligman, 1981).

5 Feldstein, M. (1981) 'Private pensions and inflation', The American Economic Review, Vol. 71, No. 2, pp. 424-428.

6 Feldstein, M. and Seligman, S. (1981) 'Pension funding, share prices and national saving', Journal of Finance, Vol. 36, No. 4, pp. 801-824.

7 This is not much of an issue in the US since most DB plans are not indexed. Its effects, however, could be very significant in the UK even if UK price inflation has been low and stable for roughly a decade.

8 These risks and costs did not go totally unnoticed. The provision of defined contribution (DC) plans by many of the largest US employers as an alternative and sometimes as a supplement to DB pensions can be interpreted as an incremental response to the acknowledged and growing liabilities (see generally Munnell, 2006).

9 Munnell, A. (2006) 'The Shift from DB to DC', in Clark, G.L., Munnell, A., Orszag, M. (eds.) Oxford Handbook of Pensions and Retirement Income, Oxford University Press, Oxford.

10 Indeed, roughly speaking, the drop in long-term interest rates between 1999 and 2002 increased the value of DB pension liabilities by $30-40$ per cent. The future term structure of interest rates is one of the great unknowns in financing future pensions. Plain vanilla interest rate swaps, however, are a good hedge to this risk exposure.
11 UK and US differences are not negligible. For example, the UK Pension Regulator is committed to negotiating outside of insolvency; such an agency does not exist in the US. Nevertheless, our matching of UK and US regulatory counterparts is appropriate as each stymies the private sector process of resolution by making public institutions a first-order choice.

12 At the authors' recent conference on pension liabilities, it was frequently argued that while DC appears to be the future of employer-provided pensions, a set of 'best practices' is desperately needed to establish governance procedures, contribution rates and payout principles for retiree income security.

13 Questions were raised at the conference regarding the suitability of the modern corporation (with all of the competitive requirements placed upon it) to act as a guarantor of the pension. Indeed, it was argued that the decline in corporate paternalism and the declining longevity of plan sponsors compared to pension benefits suggests greater insecurity than often recognised. The lifecycle of the corporation is increasingly out of sync with the lifecycle of the pension (see conclusion in part II).

14 While most of the specific references in the paper refer to the UK and US, Canadian problems and solutions look very similar. For a more specific reference to the Canadian situation, see Keith Ambachtsheer's Pension Revolution I and Pension Revolution II (see Ambachtsheer 2006a, b).

15 Ambachtsheer, K. (2006a) 'Pension Revolution I', Financial Post, 29th March.

16 Ambachtsheer, K. (2006b) 'Pension Revolution II', Financial Post, 30th March.

17 Zion, D. and Carcache, B. (2005) 'Let The Games Begin: FASB to Tackle Pensions and OPEB', Credit Suisse: New York, November.

18 GAO. (2005) 'Recent Experiences of Large Defined Benefit Plans Illustrate Weak-nesses in Funding Rules', Government Accountability Office: Washington, DC.

19 Shiller, R. (2002) 'Bubbles, human judgment, and expert opinion', Financial Analysts Journal, Vol. 58, No. 3, pp. 18-26.

20 This raises the issue of trustees' role in the pension crisis. The current trustee model is strained. Recent research has raised questions as to the competence and consistency of trustee decision making (see Clark et al., 2006a,b).

21 Clark, G. L., Caerlewy-Smith, E. and Marshall, J. C. (2006a) 'Pension fund trustee competence: Decision making in problems relevant to investment practice', Journal of Pension Economics and Finance, Vol. 5, No. 1, pp 91-110.

22 Clark, G. L., Caerlewy-Smith, E. and Marshall, J. C. (2006b) 'The consistency of UK pension fund trustee decision making', Journal of Pension Economics and Finance, forthcoming.

23 We are not implying any element of intent by actuaries who used what was termed best practice. We simply want to highlight how best practice may have been flawed.

24 Cowling, C. A., Gordon, T. J. and Speed, C. A. (2005) 'Funding defined benefit pension schemes', British Actuarial Journal, Vol. 11, No. 3, pp 497-518.

25 Exley, C. J., Mehta, S. J. B. and Smith, B. A. (1997) 'The financial theory of defined benefit pension schemes', British Actuarial Journal, Vol. 3, No. 4, pp 835-966.

26 To actuaries' credit, other more reliable methods for pricing these liabilities remain elusive, as legislation often impedes the formation of a market in pension obligations from which a fair value could be determined. (see Jones, 2005). 
27 Jones, R. (2005) 'The Market Value of Pension Liabilities', Punter Southall Transaction Services, London: UK.

28 Assuming: 'an average retirement age of 62 in both 1982 and 2002 , an interest rate of 4 per cent, and no inflation indexing of benefits'.

29 Muir, D. and Turner, J. (2003) 'Longevity and retirement age in defined benefit pension plans'. The Roundtable Workshop sponsored by the Alfred P. Sloan Foundation on Work Options for Mature Americans, University of Notre Dame; 2003, December 8.

30 Mortality estimations are, however, different between countries. As such, according to Dorothee Franzen (private communication), if the Danish mortality tables were used in the UK context, pension deficits would be considerably smaller, suggesting there remain issues of policy and choice that merit further examination.

31 This is remarkable given that observed trends in mortality were the subject of informed 'guess-timates' nearly 30 years ago. For example, Fries 1980 using data available at that time, calculated the 'ideal' life span to be roughly 85 years. According to Fries, average life expectancy should be expected to converge towards the ideal life span, but never exceed it. Setting life-span at 85 in 1980 should have profoundly impacted actuarial practice and pension funding. Longevity estimates were, however, not fully informed by the evidence emerging in the medical research communities (see Fries, 1980).

32 Fries, J. F. (1980) 'Aging, natural death, and the compression of morbidity', The New England Journal of Medicine, Vol. 303, pp. 130-135.

33 Feldstein, M. and Morck, R. (1985) 'Pension Funding Decisions, Interest Rate Assumptions and Share Prices', in Bodie, Z., Shoven, J. (eds.) Financial Aspects of the U.S. Pension System, University of Chicago Press, Chicago.

34 Coronado, J. L. and Sharpe, S. A. (2003) 'Did pension plan accounting contribute to a stock market bubble?' Brookings Papers on Economic Activity, Vol. 2003, No. 1, pp. 323-371.

35 Picconi, M. (2004) 'The perils of pensions: Does pension accounting lead investors and analysts astray?' Working Paper, Indiana University.

36 Franzoni, F. and Marin, J. M. (2006) 'Pension plan funding and stock market efficiency', Journal of Finance, Vol. 61, No. 2, pp. 921-956.

37 See Li et al. (2004) for an alternative view that claims that pension plan systematic risk is reflected in firm equity risk.

38 Li, J., Merton, R. C. and Bodie, Z. (2004) 'Do a Firm's Equity Returns Reject the Risk of its Pension Plans?', National Bureau of Economic Research, Cambridge, MA.

39 FRS 17's mark-to-market approach had a large and unexpected impact on UK plan sponsor behavior, particular with respect to pension plan investment and management. For example, 'triennial asset mix reviews' may be obsolete due to the more stringent time pressures associated with mark-to-market accounting. This is likely to increase costs of investment management dramatically. Similar reactions in the US should be expected.

40 This is now primarily a UK phenomenon (since 1997 and the Labour Government's change of policy). The majority of US plans do not have to automatically index benefits.

41 Nevertheless, many pension funds likely had 'deflation' as a scenario, but they were not managing their decisions relative to it.

42 Coronado, J. and Hewitt, G. (2005) 'Is There A Future for Defined Benefit Pensions in the United States?' Benefits Quarterly, (Fourth Quarter).
43 For example, the UK's first attempt to directly regulate by statute employer-sponsored DB pensions came in the 1995 Pension Act, which has since been followed by the 2004 Pension Act. Paradoxically, the 1997 change in Treasury regulations denying pension funds' dividend tax credit has dramatically adversely affected plan-funding schedules.

44 Clark, G. L. (2005) 'Re-writing pension fund capitalism 1: The modern corporation and pension benefit systems in a world of perpetual motion'. Oxford University Working Papers in Employment, Work and Finance; 05-08.

45 See Ippolito (2001) where he demonstrates how the reversion tax has created a complicated and inefficient distribution of property rights within a DB pension, thereby diminishing the incentives on the part of the sponsor to properly fund the DB liability.

46 Ippolito, R. A. (2001) 'Reversion taxes, contingent benefits, and the decline in pension funding', Journal of Law \& Economics, Vol. 44, No. 1, pp. 199-232.

47 Cardinale, G., Katz, G., Kumar, J. and Orszag, M. (2005) 'Background Risk and Pensions', Institute of Actuaries London, United Kingdom, 28 November.

48 Rauh (2006) found a 'strong and significant negative response of capital expenditures to required pension contributions'. In fact, he estimated that for every dollar of mandatory contributions to the pension fund, capital expenditures would decrease by $60-70$ cents.

49 Rauh, J. D. (2006) 'Investment and financing constraints: Evidence from the funding of corporate pension plans', Journal of Finance, Vol. 61, No. 1, pp. 33-71.

50 Paradoxically, a growing firm with increasing investment and an ever-expanding work force could appear to have a DB plan that is increasingly inexpensive thanks to new participants at younger ages.

51 Fabozzi, F., Focardi, S. and Jonas, C. (2005) 'Market experience with modeling for defined-benefit pension funds: evidence from four countries', The Journal of Pension Economics and Finance, Vol. 4, No. 3 .

52 Remarks to Economic Club of Chicago on 10th February, 2005.

53 The question was raised by Teresa Ghilarducci at our recent conference whether legacy costs do in fact impact competitiveness. She argued that it was more likely that poor management of core operations had led to legacy problems. This claim, and counter-claims, are hard to distinguish since determining direct causality with respect to legacy costs is nearly impossible due to the numerous cross correlations.

54 See article by John Lippert entitled 'Detroit Breakdown', Bloomberg Markets, October 2003.

55 Mackintosh, James (2006) 'GM to Slash Liability with Pension Freeze', Financial Times, 8 March.

56 GM Annual Report: 2003. Management Discussion and Analysis of Financial Conditions and Results of Operations. Financing Structure.

57 Jensen, M. C. (1993) 'The modern industrial-revolution, exit, and the failure of internal control-systems', Journal of Finance, Vol. 48, No. 3, pp. 831-880.

58 Clark, G. L. (1993) 'Pensions and Corporate Restructuring in American Industry: A Crisis of Regulation', Johns Hopkins University Press, Baltimore.

59 See Roberts (2004) for an analysis of the firm in the new economy.

60 Roberts, J. (2004) 'The Modern Firm, Organizational Design for Performance and Growth', Oxford University Press, Oxford. 
61 Clark, G. L. and Hu, Y. (2005) Re-writing pension fund capitalism 2: The UK pensions crisis and trends in occupational pension plan benefits, 1950-2004, Oxford University Working Papers in Employment, Work and Finance 05-09.

62 Monk, A. (2007) The Knot of Contracts: The Corporate Geography of Regacy Costs, Oxford University Working Papers in Employment, Work and Finance, 07-01.

63 According to the PBGC (http://www.pbgc.gov/media/index. html).

64 The figure of 45 per cent overestimates 'current' plan coverage since this number includes those that carry deferred benefits.

65 Data according to US Bureau of Labor Statistics: see www.bls. gov for details.

66 Yankelovich, D and Meer, D (2006) 'Rediscovering market segmentation', Harvard Business Review, Vol. 84, No. 2, pp. 122-131.
67 Zingales, L (2000) 'In search of new foundations', Journal of Finance, Vol. 55, pp. 1623-1655.

68 Sass, S. (2006) 'The development of employer retirement income plans', in Clark, G.L., Munnell, A., Orszag, M. (eds.) Oxford Handbook of Pensions and Retirement Income', Oxford University Press, Oxford.

69 Johnson, R and Steuerle, E (2004) 'Promoting work at older ages: the role of hybrid pension plans in an aging population', The Journal of Pension Economics and Finance, Vol. 3, No. 3, pp. 315-337.

70 DB pensions played an important role in making early retirement possible, particularly for the current generation of retirees - chiefly those that have retired since about 1990.

71 Stammers, N (2002) 'Pensions in crisis: Where do we go from here?' Consumer Policy Review, Vol. 12, No. 5, pp. 178. 